\title{
An hydrochemical answer to a legislative demand involving health risk related to water quality
}

\author{
D. M. Bonotto and L. Caprioglio \\ Departamento de Petrologia e Metalogenia, Instituto de Geociências e \\ Ciências Exatas-UNESP, Brazil.
}

\begin{abstract}
Effluents and surface waters around an area involved with the inking of tissues at Itatiba municipality, São Paulo State, Brazil, were chemically analyzed with the purpose of evaluating the influence on the water quality of the chemicals released, as well to provide answers to legislative requirements related to the São Paulo State Register 997 published on 31 May 1976.
\end{abstract}

\section{Introduction}

Modifications in the surface water quality due to industrial activities taking place at São Paulo State, southeastern Brazil, are commonly occurring as a consequence of an accentuated economic development without appropriated planning of their effects in the environment. In many circumstances, the number and the great diversity of problems do not allow an effective action by the brazilian agencies responsible by the monitoring and control of the water quality. In other cases, however, it has been possible to identify the industry responsible for causing undesirable deliveries to the environment, with implications to health risk, and, therefore, with the occurrence of some legislative action. In general, it takes a reasonable time in Brazil for the justice to make a final decision about the responsibility of the industry, i.e. if it is "innocent" or "guilty" and, during the process, the judge often requires technical informations from specialists working at universities in order to better evaluate the situation. This investigation illustrates a typical case study affecting Jacaré 


\section{Environmental Health Risk}

stream, an affluent of Atibaia river, that drains an important industrialized area distant about $100 \mathrm{~km}$ from São Paulo city, Brazil.

\section{Historical background}

The CETESB (Companhia de Tecnologia de Saneamento Ambiental) was established in 1973 by the government of São Paulo State with the purpose of controlling the pollution of the hydrological resources, being linked to the Secretary of the Environment of the State of São Paulo. The permissible concentration limits in effluents to be released to water bodies were defined in São Paulo State by Register 997 published on 31 May 1976, being CETESB the agency responsible to verify if the emissions take place under the limiting values. Table 1 reports the standards defined by Register 997 for the emission of effluents in coastal, fresh or ground waters at São Paulo State.

Anthropogenic activities involving the use of some chemicals related to the inking of tissues are taking place before 1980 at Itatiba municipality, situated at $23^{\circ} 00^{\prime} \mathrm{S}$ and $46^{\circ} 50^{\prime} \mathrm{W}$, São Paulo State. In the period 1980-1993, CETESB observed during 12 occasions that a particular industry distant about $10 \mathrm{~km}$ from Itatiba city provided the emission of effluents to surface waters in disagreement with Register 997 for some parameters like $\mathrm{pH}$, biochemical oxygen demand and setteable solids. Thus, it was started a public civil action for environmental protection in 1993, with the industry being accused by the justice of polluting the environment (air and water).

In order to help his decision, the judge decided to apply technical support from three public universities at São Paulo State: USP (University of São Paulo), UNICAMP (University of Campinas), and UNESP (University of the State of São Paulo). The rector of each university was contacted by the judicial officer in order to designate specialists for providing technical reports involving the situation considered responsible for the beginning of the action. USP decided not to participate in the action, whereas UNICAMP supplied a technical report in 1997. The results of the evaluation performed by UNESP are described in this paper.

\section{Initial steps}

With the aim of supplying the justice with a technical report, it was realized a visit to the industry in 10 December 1997 , which was not noticed in advance about its purpose. The arrival time corresponded to 15:00 hs., being initially possible to know the installations and main aspects of the activities in course. The major features of the industrial process are summarized in the simplified sketch map represented in Figure 1. The plant for the treatment of residues includes the existence of tanks for realizing the mixing of the effluents (equalization), their neutralization, aeration, and decantation, after of which, the supernatant phase is discharged into a small air-open channel, connected to Jacaré stream (Fig. 1). 
Table 1: Permissible concentration limits in effluents established by São Paulo State Register 997 published on 31 May 1976.

\begin{tabular}{|c|c|c|}
\hline PARAMETER & UNIT & VALUE \\
\hline $\mathrm{pH}$ & - & between 5 and 9 \\
\hline Temperature & ${ }^{\circ} \mathrm{C}$ & $<40$ \\
\hline Settleable solids & $\mathrm{mL} / \mathrm{L}$ & $<1$ \\
\hline Oil and grease & $\mathrm{mg} / \mathrm{L}$ & $<100$ \\
\hline $\mathrm{BOD}^{1}$ & $\mathrm{mg} / \mathrm{L}$ & $<60$ \\
\hline Arsenic & $\mathrm{mg} / \mathrm{L}$ & $<0.2$ \\
\hline Barium & $\mathrm{mg} / \mathrm{L}$ & $<5$ \\
\hline Boron & $\mathrm{mg} / \mathrm{L}$ & $<5$ \\
\hline Cadmium & $\mathrm{mg} / \mathrm{L}$ & $<0.2$ \\
\hline Lead & $\mathrm{mg} / \mathrm{L}$ & $<0.5$ \\
\hline Cyanide & $\mathrm{mg} / \mathrm{L}$ & $<0.2$ \\
\hline Copper & $\mathrm{mg} / \mathrm{L}$ & $<1$ \\
\hline Hexavalent chromium & $\mathrm{mg} / \mathrm{L}$ & $<0.1$ \\
\hline Total chromium & $\mathrm{mg} / \mathrm{L}$ & $<5$ \\
\hline Phenols & $\mathrm{mg} / \mathrm{L}$ & $<0.5$ \\
\hline Tin & $\mathrm{mg} / \mathrm{L}$ & $<4$ \\
\hline Soluble Iron $\left(\mathrm{Fe}^{2+}\right)$ & $\mathrm{mg} / \mathrm{L}$ & $<15$ \\
\hline Fluoride & $\mathrm{mg} / \mathrm{L}$ & $<10$ \\
\hline Soluble Manganese $\left(\mathrm{Mn}^{2+}\right)$ & $\mathrm{mg} / \mathrm{L}$ & $<1$ \\
\hline Mercury & $\mathrm{mg} / \mathrm{L}$ & $<0.01$ \\
\hline Nickel & $\mathrm{mg} / \mathrm{L}$ & $<2$ \\
\hline Silver & $\mathrm{mg} / \mathrm{L}$ & $<0.02$ \\
\hline Selenium & $\mathrm{mg} / \mathrm{L}$ & $<0.02$ \\
\hline Zinc & $\mathrm{mg} / \mathrm{L}$ & $<5$ \\
\hline
\end{tabular}

Jacare stream is a tributary of Atibaia river, whose fresh waters belong to class 2 , i.e. waters for domestic users after conventional treatment, among other purposes, as established by the national standard CONAMA (National Register No. 20 published on 18 June 1986). Several municipalities in the region utilize the waters of Atibaia river in their water-supply systems, reason by which much attention has been given to its quality.

In order to elaborate the technical report, four sampling points were chosen, as displayed in Fig. 1. The sampling point 4 corresponded to a site where the sample was taken before passing through the neutralization part of the effluents treatment station (ETS). The sampling point 1 allowed to collect the sample after passing through the decantation step, and corresponded to the same utilized by CETESB for performing the sampling during their visits to the industry. The sampling point 2 defined the discharge of the industry to the surface drainage, and represented the effect of the effluents dilution by a small tributary of Jacaré 
stream, with the water + effluents being collected immediately before to reach Jacare stream. Finally, the sampling point 3 was at Jacaré stream, upflow from the discharge of the industry, corresponding, therefore, to a place not affected by the release of the industrial residues under investigation.

A teflon $1-\mathrm{m}$ long $(1000 \mathrm{~mL})$ bailer with a ball valve that closes during the material retrieval was utilized to take all samples. The samples were stored in 1-5 $\mathrm{L}$ polyethylene/borosilicate glass bottles, and, depending on the requirements of the analysis, they were unpreserved/preserved with different reagents and kept cool $\left(4^{\circ} \mathrm{C}\right)$. The parameters selected for chemical analyses of the effluents and from surface waters were those reported in Table 1, with exception of oil and grease, tin, and mercury. Temperature and $\mathrm{pH}$ readings were obtained in situ, whereas other measurements were performed after transferring the samples into LABIDRO (Laboratory of Isotopes and Hydrochemistry) of Petrology Department from Geosciences and Exacts Sciences Institute that belongs to UNESP, situated at Rio Claro city, about $130 \mathrm{~km}$ distant from the investigated area.

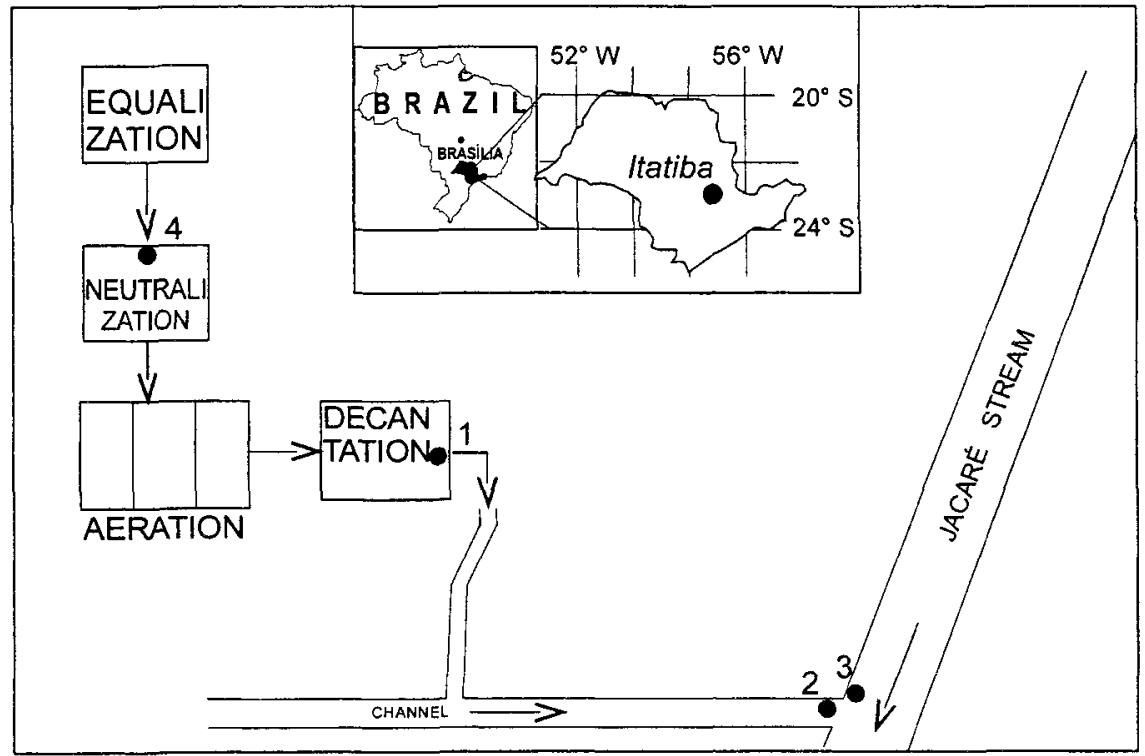

Figure 1: Location of Itatiba city at São Paulo State, Brazil, and simplified sketch map of the studied area.

\section{Analytical methods and results}

Standard analytical techniques were used for obtaining the parameters established by São Paulo State Register 997 for the release of effluents into the waters, for example, dilution and incubation method, gravity separation, potentiometry, ion selective electrode, and spectrophotometry [1-5]. Portable 
meters were used for in situ measurements of temperature and $\mathrm{pH}$, with the equipment calibration being performed immediately before the analyses. The settleability of the solids in the samples was evaluated by a clear borosilicate glass Imhoff cone $0-1000 \mathrm{~mL}$ calibrated. The BOD (Biochemical Oxygen Demand) was measured by the dilution method, employing high purity distilled water provided by Barnstead Mega-Pure One Liter Water Still. For this purpose, the dissolved oxygen (DO) content remaining in six portions of each well-mixed sample transferred to separated $300-\mathrm{mL}$ glass-stoppered bottles was evaluated after a five-day incubation period; the $\mathrm{DO}$ values measured potentiometrically by using a dissolved oxygen probe were plotted against the $\mathrm{mL}$ of sample taken, yielding a straight line that allowed to obtain the BOD data.

Fluoride was measured potentiometrically after adding a known amount of ionic strength adjustor to each sample; a Orion ion-selective electrode coupled into a digital meter was used, where standards containing $0.02,0.2$ and $2 \mathrm{mg} / \mathrm{L}$ of fluoride were utilized for preparing the calibration curve consisting on a logarithmic straight line involving the potential and concentration readings. Phenols were evaluated by the 4-aminoantipyrine method, which is based on a reaction occurring in the presence of potassium ferricyanide to form a colored antipyrine dye that is extracted from aqueous solution with chloroform, being the color measured by Hach DR/2000 spectrophotometer at $460 \mathrm{~nm}$. Boron was also determined by the same spectrophotometer, but at $605 \mathrm{~nm}$, due to its reaction with carminic acid in the presence of $\mathrm{H}_{2} \mathrm{SO}_{4}$, that produces a reddish to bluish color.

The Hach Arsenic Distillation Apparatus and Cyanide Distillation Set were used for initial preparation of the samples for analysis. The pyridine-pyrazolone method used for measuring cyanide gives an intense blue color with free cyanide, readable by Hach DR/2000 spectrophotometer at $612 \mathrm{~nm}$. Reduction of arsenic to arsine gas by a mixture of zinc, stannous chloride, potassium iodide and $\mathrm{HCl}$ occurs at the distillation apparatus. The arsine is passed through a scrubber containing cotton saturated with lead acetate and then into an absorber tube containing silver diethyldithiocarbamate in pyridine; the arsenic reacts to form a red complex with is read colorimetrically at $520 \mathrm{~nm}$.

The other metals $\mathrm{Ba}, \mathrm{Cd}, \mathrm{Pb}, \mathrm{Cu}, \mathrm{Cr}, \mathrm{Cr}^{6+}, \mathrm{Fe}, \mathrm{Mn}, \mathrm{Ni}, \mathrm{Ag}$, Se, and $\mathrm{Zn}$ were also measured colorimetrically, in some cases after the use of acid digestion and heat with Hach Digesdahl Digestion Apparatus to break the dissolved compounds into their components, able to be analyzed. The amount of turbidity present in a fine white barium sulfate precipitate was read at $450 \mathrm{~nm}$ in order to supply the $\mathrm{Ba}$ concentration data. Cadmium/lead ions in basic solution reacted with dithizone to form a pink to red cadmium/lead-dithizonate complex, extracted with chloroform and read at $515 \mathrm{~nm}$. The porphyrin indicator formed an yellow-colored complex with any free copper in sample, which was read at $425 \mathrm{~nm}$. $\mathrm{Cr}$ and $\mathrm{Cr}^{6+}$ were determined on using 1,5-diphenylcarbohydrazide, which reacts to give a purple color read at $540 \mathrm{~nm}$ when $\mathrm{Cr}^{6+}$ is present. The 1,10 phenanthroline indicator formed an orange color in proportion to the iron concentration, which was read at $510 \mathrm{~nm}$. An ascorbic acid reagent was used initially to reduce all oxidized forms of manganese, and, then, an indicator was 
added to combine with the $\mathrm{Mn}^{2+}$ to form an orange-colored complex read at 560 $\mathrm{nm}$. The nickel was reacted with 1-(2-pyridylazo)-2-naphthol indicator, being the color developed also read at $560 \mathrm{~nm}$. If present, silver ions in basic solution react with cadion $2 \mathrm{~B}$ to form a green to brownish/red-purple silver-cadion $2 \mathrm{~B}$ complex, as well read at $560 \mathrm{~nm}$. Diaminobenzidine reacted with all selenium present as selenite $\left(\mathrm{Se}^{4+}\right)$ to give a yellow-colored piazselenol complex extracted with toluene and read at $420 \mathrm{~nm}$. The zinc reacted with 2-carboxy-2'-hydroxy5 '-sulfoformazyl benzene (zincon) indicator, yielding a blue complex read at 620 $\mathrm{nm}$. Table 2 reports the results of all field and laboratory measurements.

Table 2: Chemical analyses of effluents and surface waters from the studied area.

\begin{tabular}{cccccc}
\hline PARAMETER & UNIT & $\begin{array}{c}\text { SAMPLE } \\
\text { No. } 1\end{array}$ & $\begin{array}{c}\text { SAMPLE } \\
\text { No. } 2\end{array}$ & $\begin{array}{c}\text { SAMPLE } \\
\text { No. } 3\end{array}$ & $\begin{array}{c}\text { SAMPLE } \\
\text { No. } 4\end{array}$ \\
\hline Sampling date & - & $12 / 10 / 97$ & $12 / 10 / 97$ & $12 / 10 / 97$ & $12 / 10 / 97$ \\
Time of sampling & $\mathrm{hs}$. & $16: 30$ & $17: 20$ & $17: 40$ & $18: 15$ \\
$\mathrm{pH}$ & - & 7.53 & 7.60 & 6.60 & 7.35 \\
Temperature & ${ }^{\circ} \mathrm{C}$ & 36 & 31 & 29 & 35 \\
Settleable solids & $\mathrm{mL} / \mathrm{L}$ & 2.5 & 11 & 0.7 & 0.1 \\
BOD $^{1}$ & $\mathrm{mg} / \mathrm{L}$ & 11.8 & 11.2 & 18.2 & 29.7 \\
Arsenic & $\mathrm{mg} / \mathrm{L}$ & 0.04 & 0.04 & 0.04 & 0.04 \\
Barium & $\mathrm{mg} / \mathrm{L}$ & $<1$ & $<1$ & 10 & 24 \\
Boron & $\mathrm{mg} / \mathrm{L}$ & 0.7 & 0.5 & 0.3 & 0.8 \\
Cadmium & $\mathrm{mg} / \mathrm{L}$ & 0.015 & 0.013 & 0.011 & 0.014 \\
Lead & $\mathrm{mg} / \mathrm{L}$ & 0.026 & 0.025 & 0.027 & 0.051 \\
Cyanide & $\mathrm{mg} / \mathrm{L}$ & $<0.0043$ & $<0.0043$ & $<0.0043$ & $<0.0043$ \\
Copper & $\mathrm{mg} / \mathrm{L}$ & 0.01 & 0.03 & 0.05 & 0.03 \\
Hexavalent chromium & $\mathrm{mg} / \mathrm{L}$ & 0.06 & 0.04 & 0.05 & 0.10 \\
Total chromium & $\mathrm{mg} / \mathrm{L}$ & 0.06 & 0.04 & 0.05 & 0.10 \\
Phenols & $\mathrm{mg} / \mathrm{L}$ & 0.014 & $<0.0047$ & 0.023 & 0.086 \\
Iron & $\mathrm{mg} / \mathrm{L}$ & 0.27 & 0.26 & 0.41 & 0.47 \\
Fluoride & $\mathrm{mg} / \mathrm{L}$ & 2.5 & 2.5 & 2.3 & 2.5 \\
Manganese & $\mathrm{mg} / \mathrm{L}$ & 0.036 & 0.051 & 0.025 & 0.069 \\
Nickel & $\mathrm{mg} / \mathrm{L}$ & 0.115 & 0.071 & 0.004 & 0.071 \\
Silver & $\mathrm{mg} / \mathrm{L}$ & $<0.015$ & $<0.015$ & $<0.015$ & $<0.015$ \\
Selenium & $\mathrm{mg} / \mathrm{L}$ & 0.02 & $<0.01$ & 0.01 & 0.11 \\
Zinc & $\mathrm{mg} / \mathrm{L}$ & 0.96 & 0.39 & 0.28 & 0.30 \\
\hline
\end{tabular}

${ }^{1} \mathrm{BOD}=$ Biochemical Oxygen Demand $\left(5\right.$ days, $\left.20^{\circ} \mathrm{C}\right)$

\section{Expert evaluation and consequences}

The chemical data obtained for all samples are plotted in Figs. 2, 3, and 4, which also include the maximum (as well the minimum in the case of $\mathrm{pH}$ ) permissible concentration limits for the release of effluents established by São Paulo State Register 997 (Table 1). The graphs clearly show that the Register 997 limit is not 


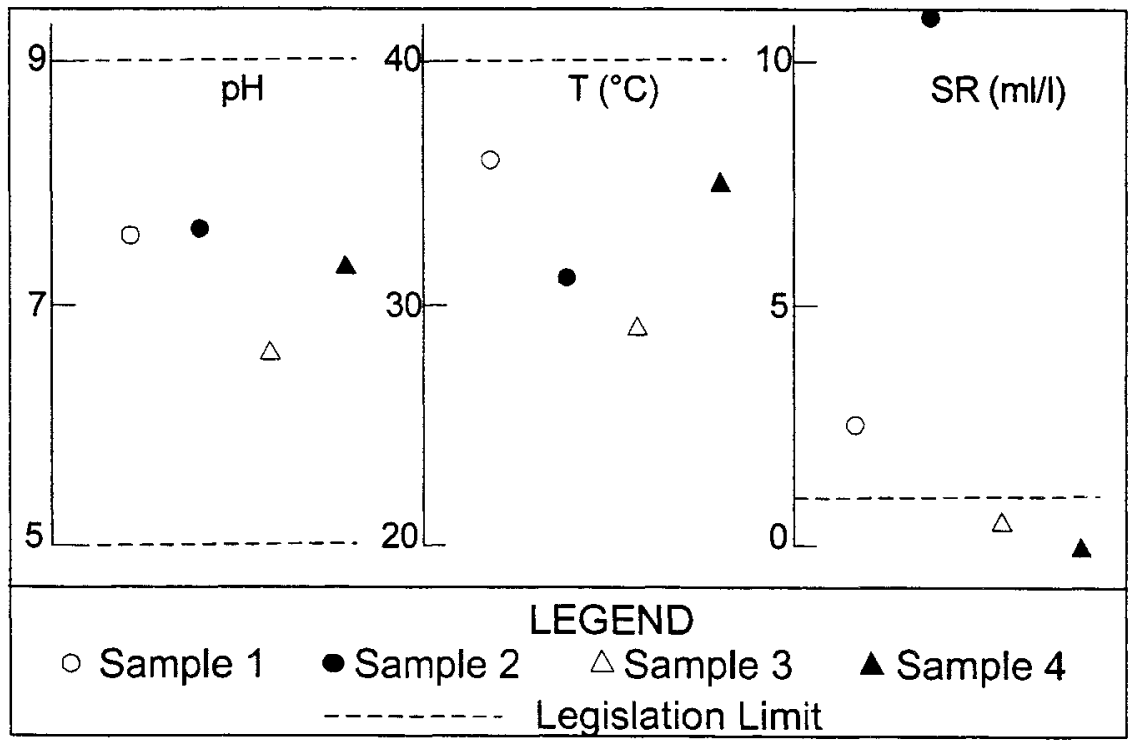

Figure 2: The $\mathrm{pH}$, temperature, and settleable solids for samples from the studied area plotted in relation to the limits established by São Paulo State Register 997.

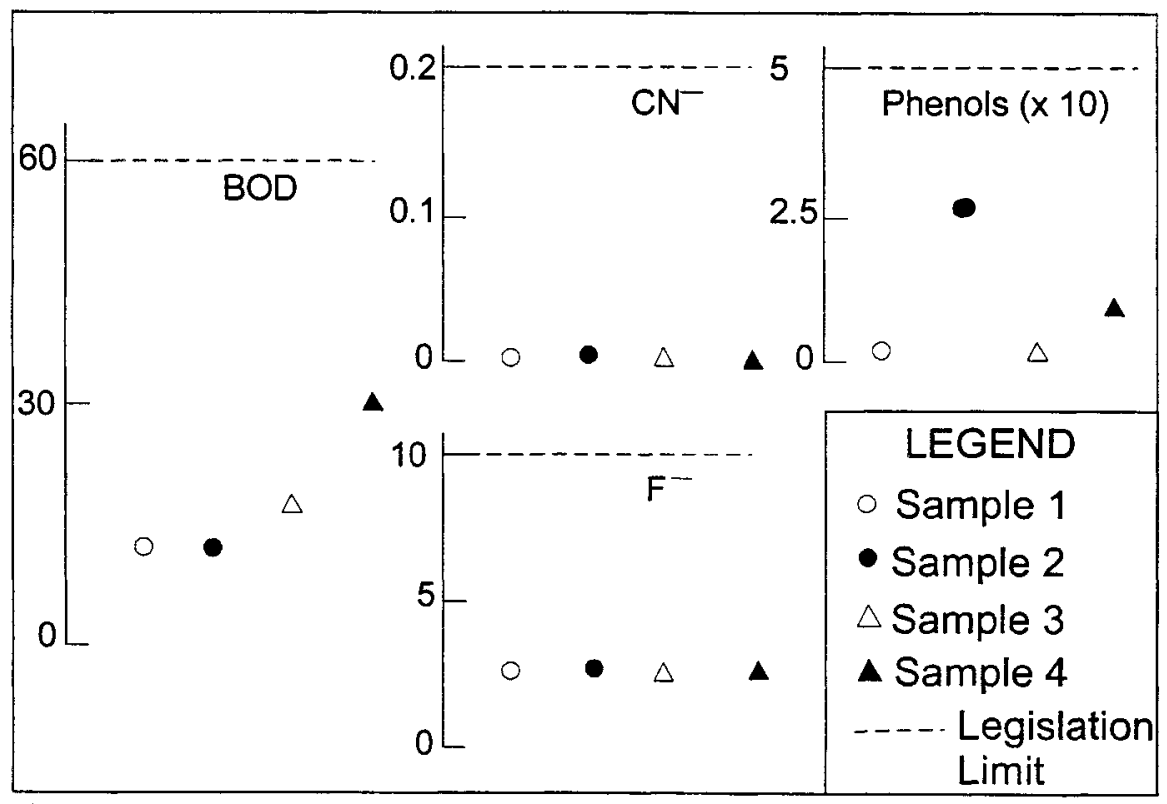

Figure 3: BOD-biochemical oxygen demand, phenols, cyanide, and fluoride contents (in $\mathrm{mg} / \mathrm{L}$ ) for samples from the studied area plotted in relation to the limits established by São Paulo State Register 997. 


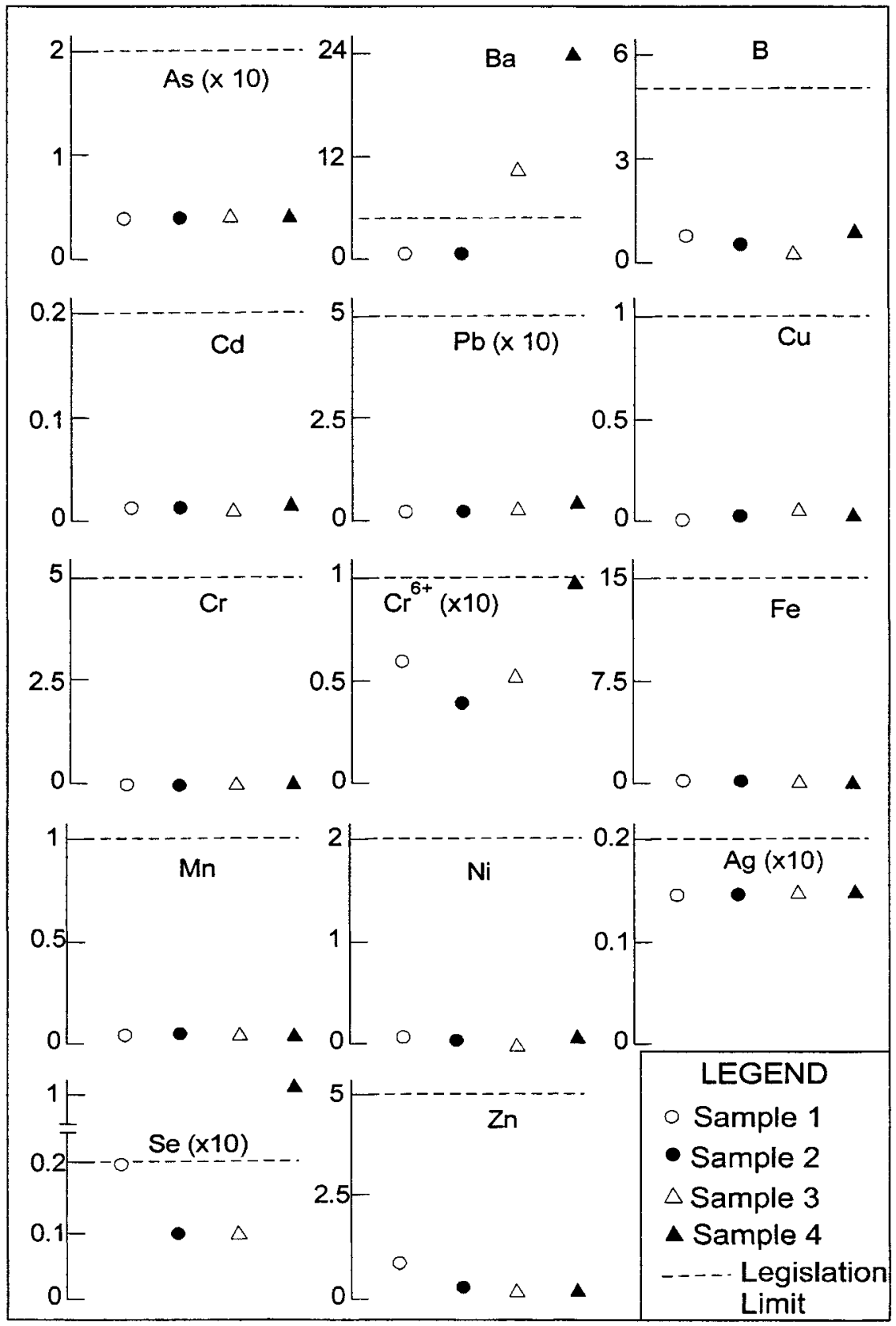

Figure 4: Boron, arsenic, selenium, and metals contents (in $\mathrm{mg} / \mathrm{L}$ ) for samples from the studied area plotted in relation to the limits established by São Paulo State Register 997. 
exceeded for practically all analyzed parameters, except in some cases now considered.

The first curious situation involves barium and selenium at sampling point 4 (Fig. 4), which are higher than the limiting values, being indicative that the effluents treatment station is effective for reducing their release into the drainage, as also demonstrated the low values found at sampling points 1 and 2 . Furthermore, in the case of barium, the value found at Jacaré stream upflow from the discharge of the industry (sampling point 3 ) is higher than that released by the industry (sampling point 2), suggesting that, in terms of this element, there is no responsibility of the accused for the pollution of the surface drainage.

However, the situation modifies when the settleable solids are taken into account (Fig.2). It is evident that occurs a release above the limiting value corresponding to $1 \mathrm{~mL} / \mathrm{L}$, as indicated the results obtained for two samples: the first collected after passing the solution through the decantation step of the effluents treatment station (sampling point 1), and the second collected immediately before the solution to reach Jacare stream (sampling point 2), being representative of the discharge of the industry into the surface drainage. It is interesting to consider that CETESB also verified such improper release in four occasions between 1982 and 1993, allowing their data the beginning of the public civil action for environmental protection.

A report containing all these considerations was submitted to the judge. The defendant of the industry argued, among other aspects, that the air-open channel also receives effluents from the basin upwards, and, consequently, the settleable solids corresponding to $11 \mathrm{~mL} / \mathrm{L}$ (sampling point 2) could represent fine soil particles not released by the accused industry. Thus, another report was necessary to be prepared, which told that the composition of the settleable solids at sampling point 2 differs from fine soil particles, as well that the value of 0.7 $\mathrm{mL} / \mathrm{L}$ obtained at Jacaré stream (sampling point 3 ) could properly represent the contribution of the basin upwards, since fine soil particles were responsible by the obtained reading.

The process continued during several months after the submission of the new report, with the defendant having included more arguments considered necessary to avoid any penalty to the industry. The described public civil action for environmental protection finalized in May 2000, corresponding to 7 years its total duration, a period that can be considered not much long when compared with those verified for other processes involving environmental aspects.

The judge decided for none responsibility of the industry for the pollution of the environment. So, despite the presented technical arguments, the judge preferred not to take them into account for giving his decision, suggesting that other factors were also considered in his judgment. Such situation well illustrates the complexity of the evaluation of the problems affecting the environment, since they frequently extrapolate technical aspects, having political, social, and economic implications. Perhaps the judge may have considered important in the described situation, for instance, eventual social problems (unemployment) possible to happen in the case of a failure of the industry caused by the need of 
payment of the costs related to the process. It is evident that if such or other criterion was used, then, unfortunately, the adopted decision did not indicate much preoccupation with health risks related to a decrease of the water quality.

\section{References}

[1] APHA (American Public Health Association) Standard Methods for the Examination of Water and Wastewater, 17 edn., Port City Press: Baltimore, 1989.

[2] HACH Water Analysis Handbook, 2 edn., Hach Company: Loveland, 1992.

[3] Fresenius, W., Quentin, K.E. \& Schneider, W. Water Analysis, SpringerVerlag: Berlin, 1988.

[4] Covington, A.K. Ion-Selective Electrode Methodology, CRC Press, Inc.: Boca Raton, 1979.

[5] Van Loon, J.C. Chemical Analysis of Inorganic Constituents of Water, CRC Press, Inc.: Boca Raton, 1979. 